\title{
PULSED PLASMA SURFACE MODIFICATION OF GREY CAST IRON
}

\author{
Yu. G. Chabak*(D), T. V. Pastukhova®, V. G. Efremenko**(i),

 \\ e-mail: *julia.chabak25@gmail.com, **vgefremenko@gmail.com \\ Pryazovskyi State Technical University, \\ 7, Universytets'ka St., Mariupol, UA-87555, Ukraine \\ (Received 08 April 2020; accepted 12 May 2020; published online 29 May 2020)
}

\begin{abstract}
The work is devoted to the investigation of the effect of high-energy pulsed plasma treatment on the surface modification and tribological characteristics of grey cast iron with the initial microhardness of about $220 \mathrm{HV}$. The modification was performed in the air atmosphere using an electro-thermal axial plasma accelerator with an arc discharge voltage of $3.0 \mathrm{kV}$ and $4.0 \mathrm{kV}$ to produce a plasma flux with a power density of $1.0 \cdot 10^{9} \mathrm{~W} / \mathrm{m}^{2}$ and $1.75 \cdot 10^{9} \mathrm{~W} / \mathrm{m}^{2}$ respectively. The study was carried out using numerical modelling, optical (Eclipse M200 Nikon) and electron scanning (JSM-6510 JEOL) microscopy, EDX (JED-2300 JEOL), X-ray diffraction (X'Pert PRO PANalytical diffractometer with $\mathrm{CuK} \alpha$ source), microhardness measurement, and wear testing according to "Three-body abrasion" ( $\mathrm{Al}_{2} \mathrm{O}_{3}$ sand) and dry-sliding "Ball-on-Disk" schemes. The results showed that a single plasma impulse with a power density of $1.0 \cdot 10^{9} \mathrm{~W} / \mathrm{m}^{2}$ led to a surface modification of up to $12 \mu \mathrm{m}$ depth without melting to form ultrafine-grained martensite with the microhardness of 359-652 HV. An increase in power density to $1.75 \cdot 10^{9} \mathrm{~W} / \mathrm{m}^{2}$ resulted in a modification of up to $28 \mu \mathrm{m}$ depth while the surface was melted to 10-12 $\mu \mathrm{m}$ depth. Under the melting the graphite dissolved causing a carbon-enrichment of the melt with a consequential formation of ultra-fine "Ledeburite" eutectic cells and high-carbon martensite having microhardness of 697-817 HV. Plasma-induced surface dopping by cathode elements (W, Cu) through the melt resulted in the crystallization of globular carbide WC and in over-enrichment of ferrite by copper (of about 3 wt. \%). The solute trapping of copper in the ferrite lattice occurred due to the ultra-high cooling rate $\left(2 \cdot 10^{6} \mathrm{~K} / \mathrm{s}\right)$ after the plasma-induced heating. The pulsed-plasma modification of grey cast iron led to a two-fold increase in its abrasive wear resistance while the dry-sliding friction coefficient was slightly increased too due to the worsening of self-lubrication caused by the graphite dissolution.
\end{abstract}

Key words: pulsed plasma treatment, modification, microstructure, microhardness.

DOI: https://doi.org/10.30970/jps.24.2501

\section{INTRODUCTION}

Surface engineering technologies are increasingly used in practice to enhance the service life of machine parts and tools. The development of these technologies has received a strong impetus with the emergence of new methods of material processing, such as PVD, laser beam exposure, irradiation with high-power electron beams, ultrasonic impact treatment, etc. [1-4]. These methods make it possible to effectively modify the microstructure and properties of the alloys. Pulse-plasma treatment (PPT) is an attractive technology for the hardening of the metallic surface [5-7] due to modification effects and protective coating deposition. Ultra-high-speed heating under plasma flux results in the formation of a modified surface layer having a fine crystalline martensitic structure [8] with increased hardness and improved resistance to brittle fracture.

Plasmotrons of different designs and working principles are used for pulse-plasma processing [5, 9-11]. Electro-thermal axial plasma accelerator (EAPA) is a plasma generator of a gas-dynamic mode operating in an atmospheric environment [12]. Previously EAPA was repeatedly used for steel surface modification and/or coating deposition [12-14]. Through the variation of the PPT mode and cathode material, the coatings of different compositions $(\mathrm{Fe}-\mathrm{C}-\mathrm{Cr}-\mathrm{Mn}, \mathrm{Fe}-\mathrm{C}-\mathrm{Cr}-\mathrm{Mn}-\mathrm{V}-\mathrm{B}$,
Fe-C-W, Ni-Cr, etc.) and thicknesses were obtained, whose microhardness reached a maximum of about 1500 HV [14]. The application of EAPA is promising for the surface hardening treatment of grey cast iron as well.

Grey cast iron is a constructive material traditionally used for machine parts. Cast iron is subjected to bulk heat treatment in order to improve its mechanical properties [15-17]. Apart from conventional heat treatment, manufacturers use alternative strengthening technologies based on highly concentrated energy sources, such as the surface strengthening of grey cast iron by Nd:YAG laser beam [18-21], steady plasma flux [22, 23], plasma nitriding [24, 25], plasma coating [26], etc. Most of these technologies involve surface melting leading to a modification of the cast iron structure through the transition from "Ferrite (Pearlite) + Lamellar (Nodular) Graphite" to the much harder "Cementite + Martensite". The latter results in a significant improvement of wear resistance and fatigue behavior [27-29]. However, there is no literature data about the use of PPT for the grey cast iron surface strengthening. Thus, the effect of PPT on the structure and properties of grey iron remains almost unexplored and attracts scientific interest. The paper deals with the study of the surface modification of grey cast iron by high-power pulsed plasma flux generated in an electro-thermal axial plasma accelerator. 

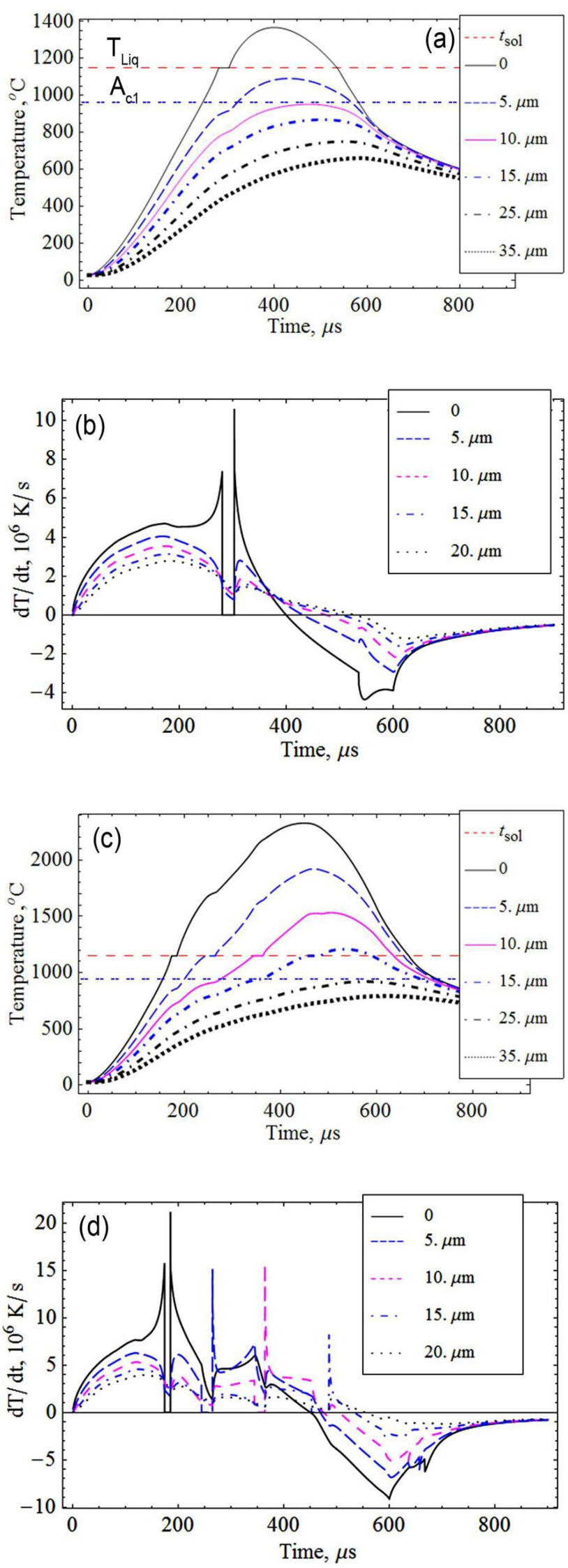

Fig. 1. Layerwise temperature distribution (a, c) and the speed of layerwise temperature change under PPT (b, d). The $q$ values are $1.0 \cdot 10^{9} \mathrm{~W} / \mathrm{m}^{2}(\mathrm{a}, \mathrm{c})$ and $1.75 \cdot 10^{9} \mathrm{~W} / \mathrm{m}^{2}$ $(b, d)$.

\section{MATERIALS AND METHODS}

In this work, grey cast iron was used as a research material with the chemical composition of 2.95 wt.\% C; 1.45 wt.\% Si; 0.95 wt. \% Mn; 0.11 wt.\% P; 0.08 wt. $\%$ S. Specimens of $7 \times 11 \times 25 \mathrm{~mm}$ size were machined from a casting of $30 \mathrm{~mm}$ diameter and $300 \mathrm{~mm}$ length. The pulse-plasma treatment of the specimens was performed using an electro-thermal axial plasma accelerator. EAPA's design and working principle are described in detail elsewhere [12-14]. The working parameters of EAPA were as follows: discharge duration was about $0.6 \mathrm{~ms}$; arc discharge current was up to $18 \mathrm{kA}$; distance between the electrodes inside EAPA was $50 \mathrm{~mm}$; distance from EAPA's edge to the target surface was 50 $\mathrm{mm}$; the pressure was atmospheric; the number of pulses was one. An axially positioned electrode (cathode) was a steel rod of $6 \mathrm{~mm}$ diameter. A tungsten rod of $3 \mathrm{~mm}$ diameter was attached to the tip of the steel rod using a copper mount. Two modes of PPT were applied differing in the surface density of the heat flux. Specifically, mode I and mode II used a capacitor charging voltages of up to $3.0 \mathrm{kV}$ and $4.0 \mathrm{kV}$, respectively. Mode I was expected to result in a surface modification without melting while mode II was expected to provide a surface melting.

PPT-treated specimens were prepared for microstructural observation according to the routine procedure of grinding and polishing. The polished surface was etched with a $4 \%$-nital reagent. The microstructure was explored using an optical microscope Eclipse M200 Nikon and a scanning electron microscope JSM-6510 JEOL. The phase chemical composition was studied using energy-dispersive X-spectroscopy (EDX) (JED-2300 JEOL). X-ray diffraction was performed using X'Pert PRO PANalytical diffractometer with $\mathrm{CuK} \alpha$ source. The microhardness of the samples was measured on a microhardness tester FM-300 Future-Tech Corp. with a load of $20 \mathrm{~g}$. For the microhardness value, the average of 10 measurements was taken for each specimen.

The wear test was carried out according to the "Threebody abrasion" scheme. The specimen was abraded by the abrasive particles $\left(\mathrm{Al}_{2} \mathrm{O}_{3}\right.$ being pressed to a rubber roller of $40 \mathrm{~mm}$ diameter rotating at a speed of $10.8 \mathrm{~s}-1$. The weight loss in the specimens was measured after each "one minute"-cycle of the tests. The total test duration was 10 min (i.e. it consisted of 10 cycles). The weight loss was measured by electronic balance with the accuracy of $0.1 \mathrm{mg}$. The test for dry-sliding behavior was performed by the "Ball-on-Disc" scheme using the "Micron-tribo" tribometer. The variation in the friction coeffcient was calculated against a hardened steel ball of $5 \mathrm{~mm}$ diameter at a load of $500 \mathrm{~g}$.

\section{RESULTS AND DISCUSSION}

\section{A. The modeling of the plasma-induced temperature field}

The temperature field in the cast iron specimen induced by pulsed-plasma flux under PPT was calculated using the numerical model proposed in [12]. The 

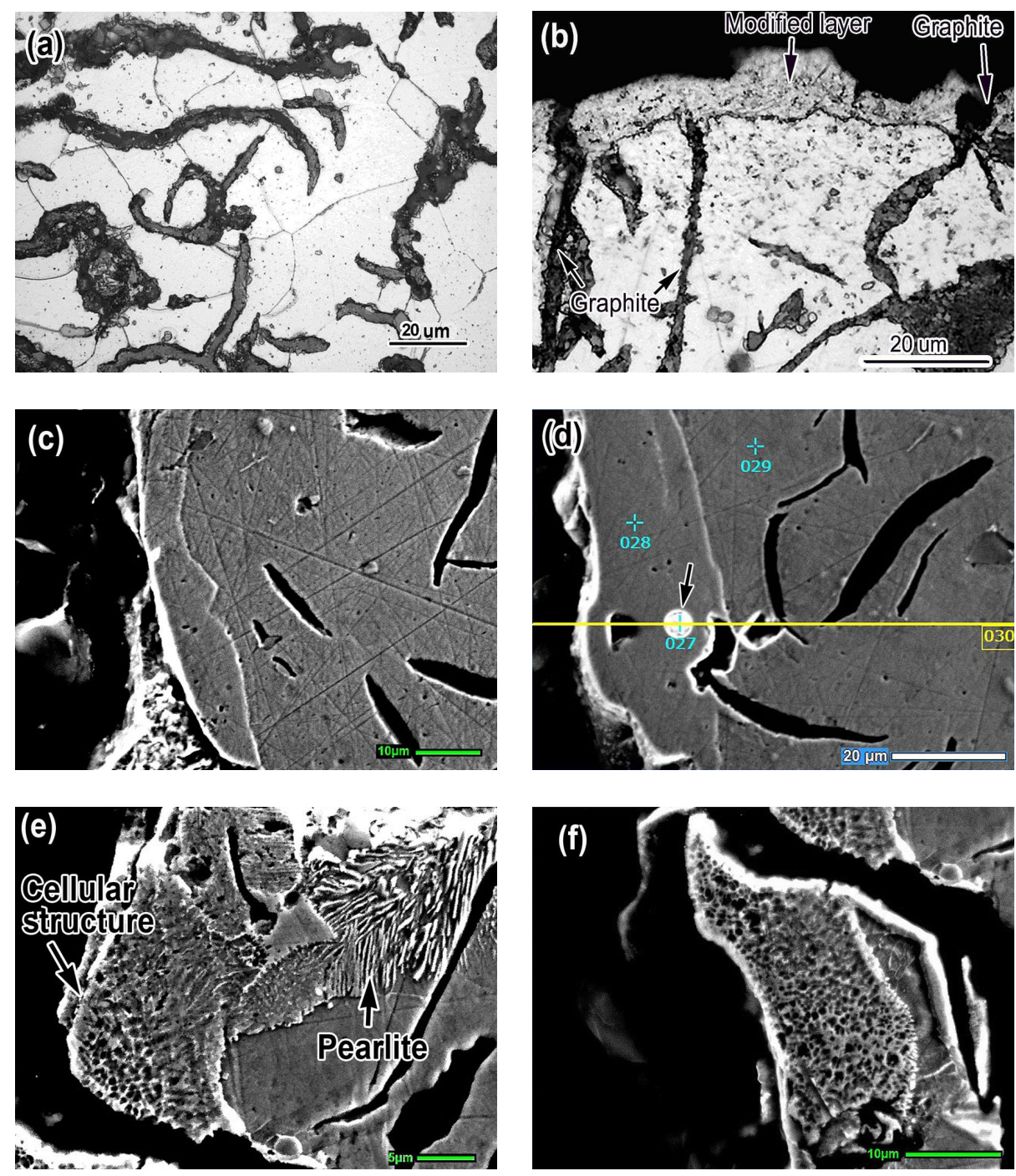

Fig. 2. The microstructure of the specimens studied: a bulk structure (a), pulsed-plasma treatment with $q=1.0 \cdot 10^{9} \mathrm{~W} / \mathrm{m}^{2}$ $(\mathrm{b}, \mathrm{c})$ and $q=1.75 \cdot 10^{9} \mathrm{~W} / \mathrm{m}^{2}(\mathrm{~d}-\mathrm{f})$.

temperature dependences of the thermophysical quantities of gray cast iron (density, thermal conductivity, specific heat) were adopted from [30]. The calculations were performed for the surface density of heat sources (q) of $1.0 \cdot 10^{9} \mathrm{~W} / \mathrm{m}^{2}$ and $1.75 \cdot 10^{9} \mathrm{~W} / \mathrm{m}^{2}$ which corresponded to the charge voltages of $3.0 \mathrm{kV}$ and $4.0 \mathrm{kV}$, respectively [12]. The results of the calculations are presented in Fig. 1. As can be seen from Fig. 1,a, during PPT under $q=1.0 \cdot 10^{9} \mathrm{~W} / \mathrm{m}^{2}$, the temperature in the specimen top reaches its maximum after about $350 \mu \mathrm{s}$, meaning the average heating rate is $4 \cdot 10^{6} \mathrm{~K} / \mathrm{s}$, while the instantaneous heating rate spikes to $10.1 \cdot 10^{6} \mathrm{~K} / \mathrm{s}$ after $300 \mu$ s (Fig. 1,b). At the temperature peak, the layer at a depth of $5 \mu \mathrm{m}$ remains non-melted since its temperature is lower than the cast iron melting point $T_{\mathrm{Liq}}\left(1150^{\circ} \mathrm{C}\right.$ [30]). The temperature of critical point $\mathrm{Ac}_{1}$ is drawn on Fig. 1 to be taken as $950^{\circ} \mathrm{C}$ [12] (this temperature is shifted up from the equilibrium value of $727^{\circ} \mathrm{C}$ due to heating at a rate of $\sim 10^{6} \mathrm{~K} / \mathrm{s}$ [31]). Considering the $\mathrm{Ac}_{1}$ position, one can see that only the layers of up to $10 \mathrm{~mm}$ depth are heated up to the austenite domain (this occurred after $400 \mathrm{~ms}$ from the heating start). This value $(10 \mu \mathrm{m})$ refers to the layer depth where the modification through the "austenite-martensite" phase transformation may occur. The transformation is quite possible due to the very high cooling rate exceeding $2 \cdot 10^{6} \mathrm{~K} / \mathrm{s}$ (Fig. 1,b).

When PPT is performed with $q=1.75 \cdot 10^{9} \mathrm{~W} / \mathrm{m}^{2}$, then the surface is heated to a greater extent. Fig. 1c shows that the temperature reaches $2300^{\circ} \mathrm{C}$ on the top while the specimen melts to the depth of $15-17 \mu \mathrm{m}$. Accordingly, heating above the $\mathrm{Ac}_{1}$ temperature extends to a depth of $25 \mu \mathrm{m}$ (Fig. 1d). The heating/cooling rates reach much higher values as compared with $q=$ $1.0 \cdot 10^{9} \mathrm{~W} / \mathrm{m}^{2}$. The calculations showed that PPT under the charge voltage of $3.0 \mathrm{kV}$ is unlikely to result in surface melting, while PPT with a charge voltage of $4.0 \mathrm{kV}$ may lead to a modification through the surface melting. In both cases, the displacive (martensite) phase transformation should take place in the heated layers due to the ultra-high rate of its cooling. 


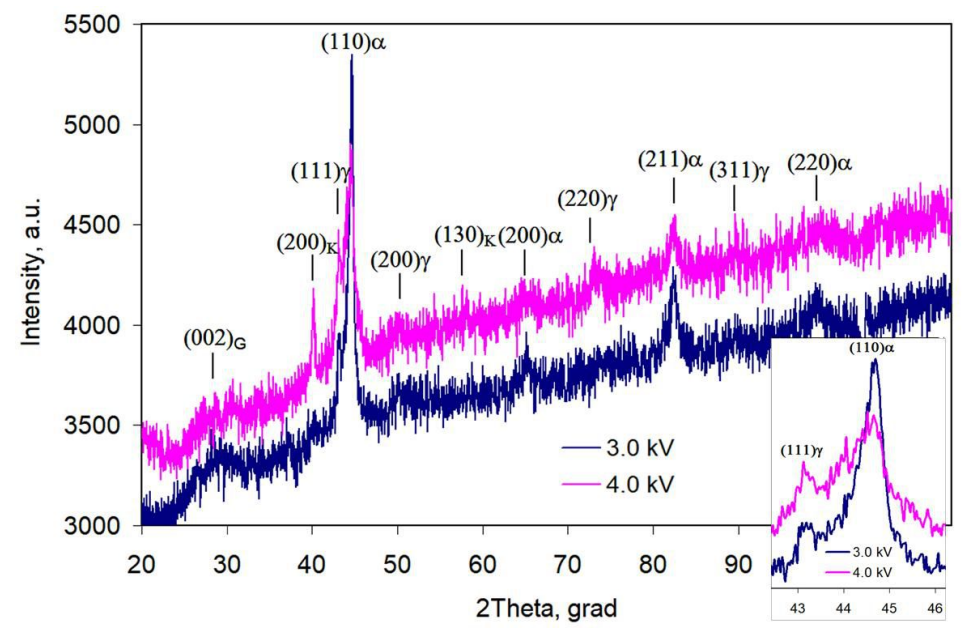

Fig. 3. XRD patterns of plasma modified specimens ( $\mathrm{G}$ - graphite, $\mathrm{K}$ - cementite carbide).

\section{B. Microstructure observation}

The initial microstructure of the specimens consisted of ferrite grains and graphite lamellas as shown in Fig. 2,a. The microhardness of ferrite was $223 \pm 25 \mathrm{HV}$. The increased ferrite microhardness was caused by the solid solution strengthening due to the presence of silicon and manganese in the matrix. The microhardness of the graphite lamellas was very low $(38-87 \mathrm{HV})$.

After PPT with a $q=1.0 \cdot 10^{9} \mathrm{~W} / \mathrm{m}^{2}$, a thin modified layer of up to $12 \mu \mathrm{m}$ depth appeared contouring the specimen surface (Fig. 2,b). The thickness of this layer nearly corresponds to that predicted by numeric modelling. Mostly this layer was free of graphite however in some areas graphite, lamellas were observed within it (Fig. 2,b). The microhardness of the modified layer was measured to be in the range of 359-652 HV. The average microhardness value $(535 \pm 88 \mathrm{HV})$ was 2.5 times higher than that of ferrite grains. Such microhardness level is characteristic of a martensite structure containing $0.3-0.4$ wt. \% C [30]. Taking into account the high heating/cooling rate under PPT it can be assumed that PPT, with $3.0 \mathrm{kV}$ voltage assured the sequential "Ferrite-Austenite-Martensite" phase transformations in a subsurface layer heated above the $\mathrm{Ac}_{1}$ temperature. Since the initial ferritic matrix contained a negligible concentration of carbon [32], the formation of martensite with the mentioned hardness implied an enrichment of austenite with carbon through the partial graphite dissolution under plasma fiux heating. Visually the layer had a homogeneous structure: no specific lath/needle martensite pattern was observed within the modified layer manifesting its ultra-fine-grained status.

The microstructure of the specimen treated at a charge voltage of $4.0 \mathrm{kV}$ is shown in Figs. 2,d-f. As can be seen, an indiscrete modified layer 14-28 $\mu$ m thick appeared on the specimen top. The roughness protrusion acquired a modified "cellular" structure 10-12 $\mu \mathrm{m}$ thick consisting of very fine cells of $0.5-1.0 \mu \mathrm{m}$ diameter (Fig. 2e,f). The cellular structure was the fine colonies of "ledeburite"-like carbide eutectic "Austenite $+\mathrm{Fe}_{3} \mathrm{C}$ (cementite)". The appearance of "Ledeburite" was caused by the full dissolution of graphite upon plasma-induced melting with further rapid non-equilibrium solidification [20-22]. This assumption was confirmed by the absence of graphite within the modified layer. The high cooling rate resulted in the very small critical nucleus of crystallization [32] leading to ultra-fine eutectic cells. Next to cellular areas the colonies of fine pearlite were observed (Fig. 2,e), also proving the carbon enrichment of the melt. Furthermore, occasional globules of bright contrast of $2.5-10 \mu \mathrm{m}$ in diameter were found within the modified layer (shown by the arrows in Figs. 2,d). The microhardness of the modified layer out of the "cellular" structure was $697-817 \mathrm{HV}$ (the average value of $747 \pm 52 \mathrm{HV}$ ), which is characteristic of martensite containing not less than $0.6 \mathrm{wt}$. \% [33]. This indicated a higher carbon concentration in the modified layer lattice.

The microstructure observation was confirmed by Xray diffraction (Fig. 3). The XRD-pattern of a $3.0 \mathrm{kV}$ treated specimen performed the peaks of $\alpha \mathrm{Fe}, \gamma \mathrm{Fe}$, and graphite. Ferrite was dominant in the structure while the presence of austenite was shown only by $(111)_{\gamma}$ peak (see inset to Fig. 3). Austenite is unusual for grey cast iron; the appearance of austenite was caused by the partial dissolution of graphite under the plasma flux resulting in lowering the temperature Ms (the start of the martensite transformation) [33]. After PPT with a charge voltage of $4.0 \mathrm{kV}$, the cementite carbide peak (200) appeared reflecting the transition from graphite to carbide. Moreover, the intensity of the austenite peak $(111)_{\gamma}$ increased while other minor peaks $(200)_{\gamma},(220)_{\gamma}$, $(311)_{\gamma}$ appeared in the XRD pattern. Instead of this, the graphite peak (002) has become less pronounced compared to the $3.0 \mathrm{kV}$-treated specimen. The XRD pattern alteration indicated that PPT with a charge voltage of $4.0 \mathrm{kV}$ initiated the following sequential transformations: (a) iron melting, (b) graphite melting to enrich the melt by carbon, (c) crystallization of highcarbon austenite, (d) eutectic reaction "L-Austenite + $\mathrm{Fe}_{3} \mathrm{C}$ ", (e) the transformation "Austenite (high-carbon)Martensite (high-carbon) + Retained Austenite". 

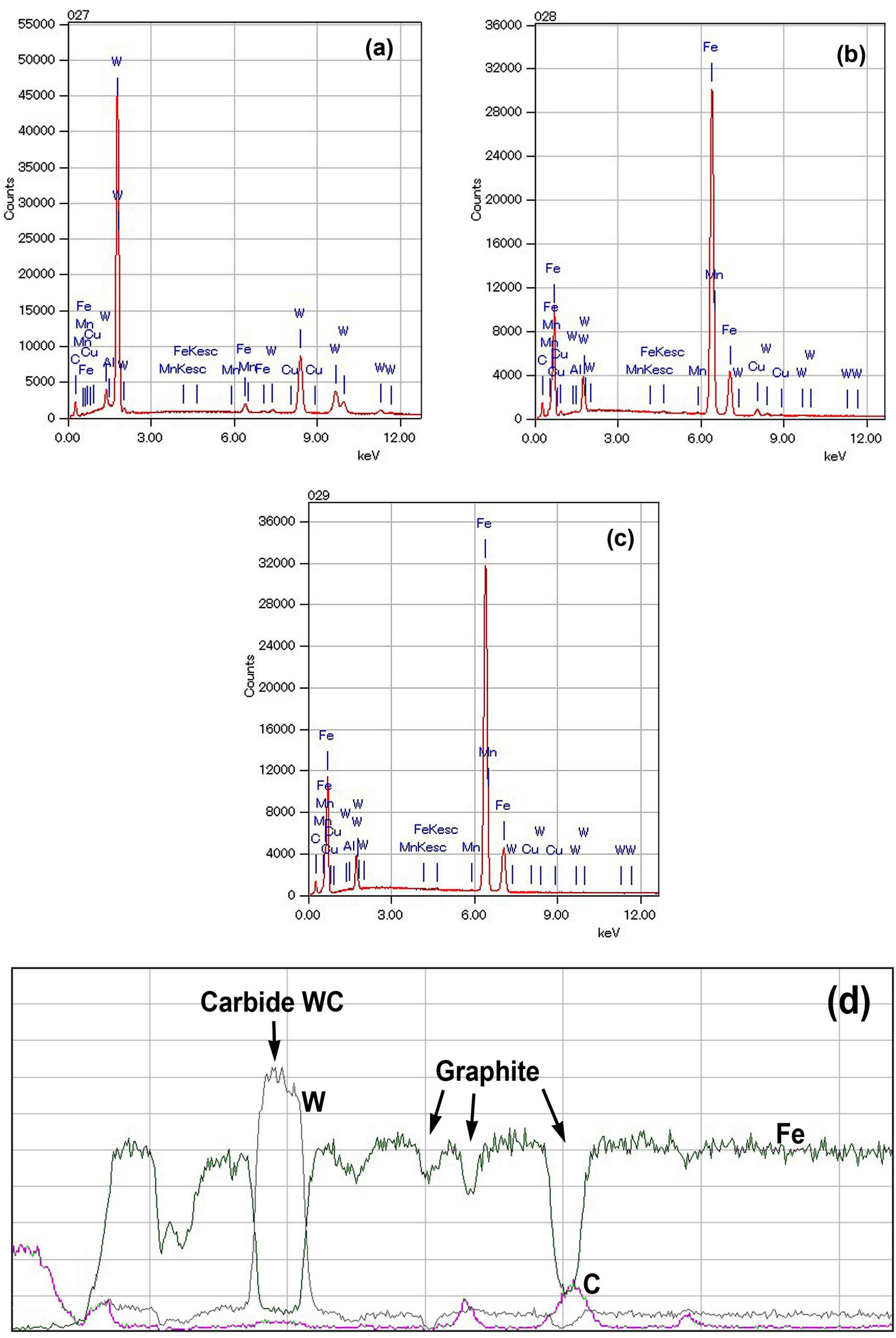

Fig. 4. The results of EDX-analyzing (Fig. 2d): EDX-spectra from the dots 27 (a), 28 (b), 29 (c); elements profiles along scanning line (d). 


\section{Phase elemental distribution}

Fig. 4 presents the results of the EDX examination of the layer modified with a voltage of $4.0 \mathrm{kV}$. The sites of the local EDX analyzing and scanning direction are depicted in Fig. 2,d. It was found that the modified layer (dot 28) contains 3.29 wt. \% Cu and 0.22 wt. \% W while these elements are absent from the substrate (dot 29) (Table). The bright globule (dot 27) consisted of tungsten (88.30 wt. \%) and carbon (8.80 wt.\%) with iron as a residue. The presence of $\mathrm{Cu}$ and $\mathrm{W}$ within the modified layer is confirmed by the corresponding EDX-spectra shown in Figs. 4,a and 4,b. The element profiles along the scanning line (Fig. 4,d) clearly identified a W-rich globule (the sharp spike in $\mathrm{W}$ ) and graphite lamellas (falls in Fe and spikes in $\mathrm{C}$ ).

According to EDX, the bright contrast globule had a stoichiometry close to tungsten carbide WC. Moreover, a tungsten trace was found in the matrix of the modified layer. These findings indicated that PPT was accompanied by the plasma transfer of cathode elements $(\mathrm{W}, \mathrm{Cu})$, which were implanted into the melt on the specimen surface. The tungsten atoms evaporated from the cathode tip (tungsten rod) under high-current discharge to be transferred by the plasma flux. WC precipitate crystallized in carbon-enriched melt in the si- tes the tungsten atoms accumulation. If the tungsten concentration in the melt is low, then tungsten remains in $\alpha$ Fe-lattice as an impurity. The presence of copper in the modified layer was also due to the erosion of the copper mount surface. The copper content in the modified layer (about $3 \mathrm{wt} . \%$ ) exceeded its limit of solubility in $\alpha$-Fe $\left(0.5\right.$ wt. $\%$ at $700^{\circ} \mathrm{C}$ [34]); however copper did not precipitate from ferrite. The ultra-fast cooling after PPT resulted in the "solute-trapping" [35], when copper stayed in the ferrite lattice contributing to the microhardness via the solid strengthening effect. Thus, the pulsed-plasma treatment made it possible to combine the modification with the surface dopping to enhance the cast iron properties.

\begin{tabular}{|c|c|c|c|c|c|c|}
\hline $\begin{array}{c}\text { Dot location } \\
\text { in Fig. 2,d }\end{array}$ & $\mathrm{C}$ & $\mathrm{Mn}$ & $\mathrm{Si}$ & $\mathrm{Cu}$ & $\mathrm{W}$ & $\mathrm{Fe}$ \\
\hline \hline 27 & 8.80 & - & - & - & 88.29 & 2.91 \\
\hline 28 & 5.64 & 0.91 & 1.45 & 3.29 & 0.22 & 88.50 \\
\hline 29 & 4.97 & 0.85 & 1.35 & 0.02 & - & 92.81 \\
\hline
\end{tabular}

Table. Local chemical composition (wt.\%) of PPT-treated cast iron
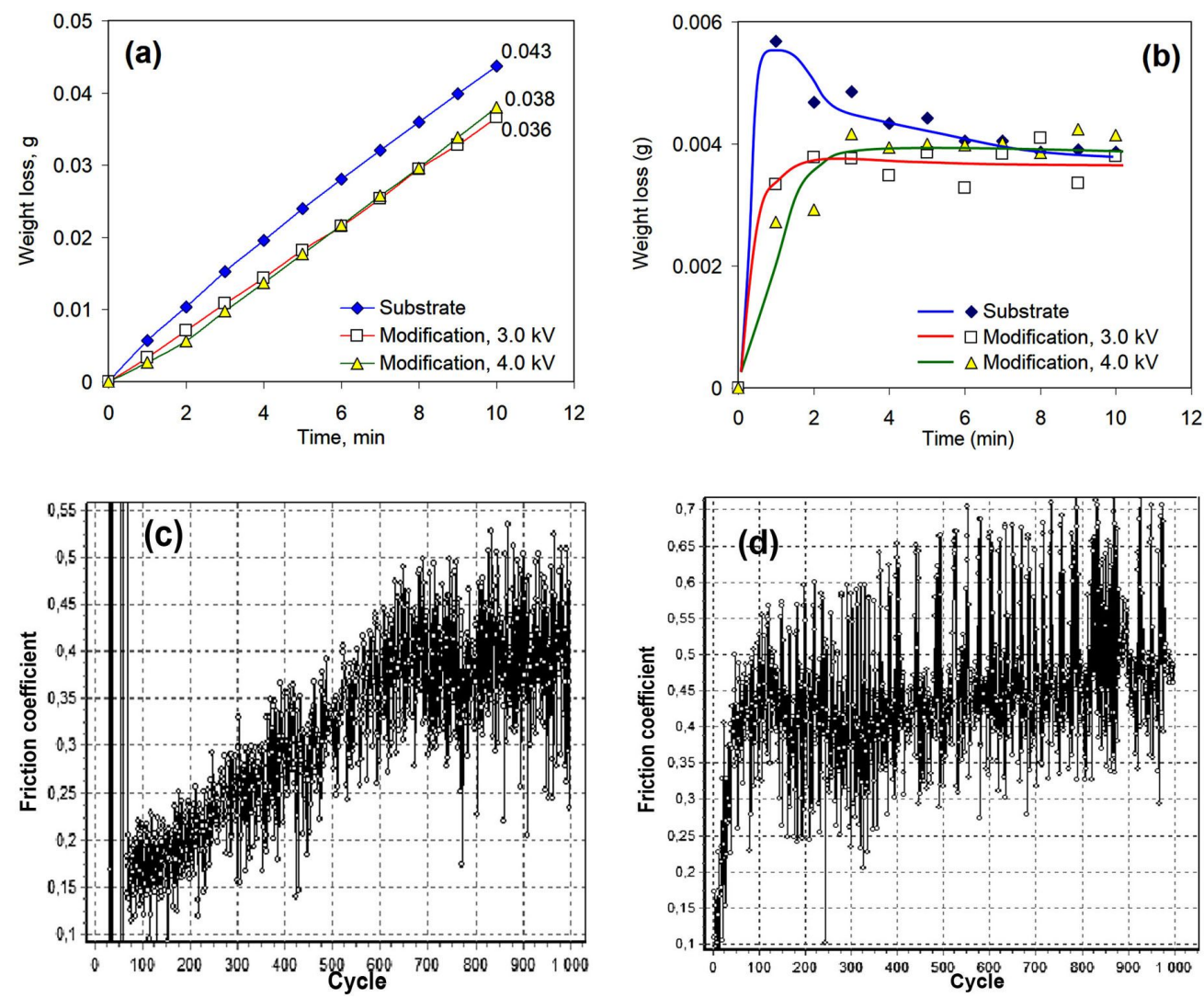

Fig. 5. Tribological behavior of PPT-modified grey cast iron: the cumulative curves of abrasive weight loss (a), the variation of abrasive "one-minute weight loss" during the testing (b), the variation of the friction coefficient during "Pin-on-Disc" testing $(\mathrm{c}, \mathrm{d}$ ) (for untreated substrate (c) and for $4.0 \mathrm{kV}$-modified specimen (d)). 


\section{Tribological characteristics}

The results of the abrasive test are shown in Fig. 5a as the cumulative weight loss curves. As can be seen, the total weight loss of untreated cast iron was $0.044 \mathrm{~g}$. The lower total weight loss $(0.0380 \mathrm{~g})$ occurred in the cast iron modified with a charge voltage of $3.0 \mathrm{kV}$. The best abrasive behavior was shown by the specimens modified with a charge voltage of $4.0 \mathrm{kV}(0.0368 \mathrm{~g})$. Based on these values, the pulsed-plasma modification increased the abrasive wear resistance of grey cast iron by 15 $19.5 \%$. A more accurate evaluation could be made using the "one-minute weight loss", which is the weight loss for one cycle of the test. At the beginning of the test, the contacting pressure of the "specimen/roller" counteraction was the highest causing a significant weight loss in the untreated cast iron. In this condition, its "one-minute weight loss" (0.0057 g) was two-fold as compared with modified specimens $(0.033 \mathrm{~g}$ for $3.0 \mathrm{kV}$ and 0.0027 for $4.0 \mathrm{kV})$. As the test continued, the contacting surface area grew, leading to an increase in the "one-minute weigh loss" in the modified layer. Thus, the advantage of the modified specimens gradually decreased until it levelled with an untreated specimen after 6 min of testing. Concluding, PPT-modification provided a doubled abrasive wear resistance until the modified layer was worn out.

The dry-sliding behavior of cast iron is depicted in Figs. 4,c,d showing the variation of the friction coefficient $(\mu)$ over 1000 friction cycles. The testing was accompanied by a gradual increase in $\mu$ value and its stabilization at a certain level. In untreated cast iron, the friction coefficient was levelled at $0.35-0.42$ with the scattering amplitude of $0.20-0.55$. For the plasma-modified specimen $(4.0 \mathrm{kV})$, the friction coefficient stabilized at 0.40 0.50 , and the oscillation amplitude increased to 0.30 0.72. Thus, the PPT-modification with the melting slightly increased the friction coefficient of grey cast iron.
This can be explained by the worsening of the surface self-lubrication caused by the dissolution of graphite lamellas.

\section{CONCLUSIONS}

It is shown that pulsed plasma treatment with a surface density of heat sources of $1.0 \cdot 10^{9} \mathrm{~W} / \mathrm{m}^{2}$ provided a modification of grey cast iron up to $12 \mu \mathrm{m}$ depth without surface melting. The modified layer consisted of martensite with the microhardness of 359-652 HV. PPT with $q=1.75 \cdot 10^{9} \mathrm{~W} / \mathrm{m}^{2}$ resulted in a modification up to $28 \mu \mathrm{m}$ depth with melting to $10-12 \mu \mathrm{m}$ depth. The melting resulted in the formation of ultra-fine cells of austenite-carbide eutectic and high-carbon martensite with a microhardness of 697-817 HV. The PPT melting was accompanied by the plasma-transferred implantation of cathode elements $(\mathrm{W}, \mathrm{Cu})$ into the modified layer, which caused the formation of tungsten carbides and "solute-trapping" of copper in the ferrite lattice. The PPT modification provided a two-fold decrease in the abrasive wear of grey cast iron due to the formation of a martensite or austenite-carbide structure in the modified layer. At the same time, the dry-sliding friction coefficient of the modified specimen slightly increased from $0.35-0.42$ to $0.40-0.50$ due to the worsening of the surface self-lubrication caused by the dissolution of graphite lamellas.

Acknowledgments. The publication contains results of the studies funded by the President of Ukraine's grant for competitive project $\Phi 82$. The work was also funded by the Ministry of Education and Science of Ukraine under project No 0119U100080. The help of Prof. K. Shimizu (Muroran Institute of Technology) and Mgr., PhD I. Petryshynets (Institute of Materials Research, Slovak Academy of Sciences) is greatly appreciated.
[1] O. V. Sobol et al., J. Nano-Electron. Phys. 11, 01003 (2019); https://doi.org/10.21272/jnep.11(1) .01003

[2] M. O. Vasylyev, B. N. Mordyuk, S. I. Sidorenko, S. M. Voloshko, A. P. Burmak, Metallofiz. Noveishie Tekhnol. 37, 1269 (2015); https://doi.org/10.15407 /mfint.37.09.1269.

[3] V. Pidkova, I. Brodnikovska, Z. Duriagina, V. Petrovskyy, Funct. Mater. 22, 34 (2015); https://doi.org/10.15407/fm22.01.034.

[4] M. O. Vasylyev, B. N. Mordyuk, S. I. Sidorenko, S. M. Voloshko, A. P. Burmak, Metallofiz. Noveishie Tekhnol. 39, 49 (2017); https://doi.org/10.15407/m fint. 39.01.0049.

[5] A. D. Pogrebnyak, Yu. N. Tyurin, Usp. Fiz. Nauk 48487 (2005); https://doi.org/10.1070/PU2005v048 n05ABEH002055.

[6] V. G. Efremenko et al., Mater. Des. 126, 278 (2017); https://doi.org/10.1016/j.matdes.2017.04.022.

[7] A. Zhukeshov, A. T. Gabdullina, A. U. Amrenova, S. A. Ibraimova, J. Nano- Electron. Phys. 6, 03066
(2014).

[8] Yong Xiang et al., J. Mater. Process. Technol. 226, 238 (2015); https://doi.org/10.1016/j.jmatprotec .2015 .07 .022 .

[9] B. Sartowska et al., Vacuum 70, 285 (2003); https:// doi .org/10.1016/S0042-207X (02) 00656-5.

[10] S. Yu. Kornilov, N. G. Rempe, Bull. Russ. Acad. Sci.: Phys. 831410 (2019); https://doi.org/10.3103/S106 2873819110133.

[11] Y. Yarali, O. H. Akbulut, M. Durman, Vacuum 122 (2015); https://doi.org/10.1016/j.vacuum. 201 5.08 .017 .

[12] Yu. G. Chabak et al., Probl. At. Sci. Technol. Ser.: Plasma Phys. 110(4), 97 (2017).

[13] Yu. G. Chabak, V. I. Fedun, V. G. Efremenko, T. V. Pastukhova, B. V. Efremenko, Probl. At. Sci. Technol. Ser.: Plasma Phys. 123(5), 167 (2019).

[14] Yu. G. Chabak et al., J. Mater. Eng. Perform. 27, 379 (2018); https://doi.org/10.1007/s11665-017-3 $102-z$.

[15] A. Gonzalez-Pociño, F. Alvarez-Antolin, J. Asensio- 
Lozano, Metals 9, 522 (2019); https://doi.org/10.3 $390 /$ met 9050522 .

[16] A. Anishchenko, V. Kukhar, V. Artiukh, O. Arkhipova, MATEC Web Conf. 239, 06006 (2018); https://doi.or $\mathrm{g} / 10.1051 /$ matec conf $/ 201823906006$.

[17] V. G. Efremenko, Yu. G. Chabak, A. Lekatou, A. E. Karantzalis, A. V. Efremenko, Metall. Mater. Trans. A 47, 1529 (2016); https://doi.org/10.1007/ s11661-016-3336-7.

[18] S. S. Aziz, A. S. Alwan, K. A. Abed, Biochem. Cell. Arch. 1, 1587 (2019); https://doi.org/10.35124/bca .2019.19.1.1587.

[19] A. R. Zulhishamuddin, S. N. Aqida, E. A. Rahim, AIP Conf. Proc. 1769, 030004 (2016); https://doi.org/10 $.1063 / 1.4963420$.

[20] N. Pagano, V. Angelini, L. Ceschini, G. Campana, Procedia CIRP 41, 987 (2016); https://doi.org/10.1 016/j.procir.2015.12.131.

[21] K. Y. Benyounis, O. M. Fakron, J. H. Abboud, A. G. Olabi, M. S. J. Hashmi, J. Mater. Process. Technol. 170, 127 (2005); https://doi.org/10.1016/j.jmatpr otec. 2005.04 .108$.

[22] X. Cheng, S. Hu, W. Song, X. Xiong, Vacuum 101, 177 (2014); https://doi.org/10.1016/j.vacuum. 201 3.08.012.

[23] B.-Y. Jeong, J.-H. Chang, M.-H. Kim, Surf. Coat. Technol. 205, 896 (2010); https://doi.org/10.1016/ j.surf coat. 2010.08.040.

[24] O. Çomaklı, A. F. Yetim, B. Karaca, A. Çelik, Mater.
Res. Express. 6, 056513 (2019); https://doi.org/10.1 088/2053- $1591 / \mathrm{ab} 012 \mathrm{~b}$

[25] Y. Dong, T. Bell, X. Li, H. Dong, Vacuum 153, 217 (2018); https://doi.org/10.1016/j.vacuum. 201 8.04 .016$.

[26] Y.-X. Zhou, J. Zhang, Z.-G. Xing, H.-D. Wang, Z.-L. Lv, Surf. Coat. Technol. 361, 270 (2019); https://doi. org/10.1016/j . surfcoat.2018.12.055.

[27] Z. B. Pang et al., Opt. Laser Technol. 70, 89 (2015); https://doi.org/10.1016/j.optlastec. 2015.01.018.

[28] Q. Sui et al., J. Mat. Res. 32, 343 (2017); https://doi: $10.1557 / \mathrm{jmr} .2016 .474$.

[29] O. Sukhova, Yu. Syrovatko, Metallofiz. Noveishie Tekhnol. Spec. Iss. 33371 (2011).

[30] E. I. Kazantsev, Promyshlennye pechi (Metallurgia, Moscow, 1975).

[31] G. Yu. Balandina, B. I. Bertiaev, I. N. Zavetovskaia, V. I. Igoshin, V. A. Katulin, Quant. Electron. 13, 2315 (1986)

[32] G. E. Totten, M. A. Howes, Steel Heat Treatment Handbook (Taylor \& Francis Inc, Bosa Roca, United States, 1997)

[33] V. G. Efremenko et al., Wear 418-419, 24 (2019); http $\mathrm{s}: / /$ doi .org/10.1016/j. wear.2018.11.003.

[34] O. K. von Goldbeck, in Iron-Binary Phase Diagrams (Springer, Berlin, 1982), p. 35.

[35] T. Zheng et al., Sci. Rep. 9, 266 (2019); https://doi. org/10.1038/s41598-018-36303-5.

\section{МОДИФІКАЦІЯ ПОВЕРХНІ СІРОГО ЧАВУНУ ПЛАЗМОВИМИ ІМПУЛЬСАМИ}

Ю. Г. Чабак, Т. В. Пастухова, В. Г. Єфременко, В. І. Зурнаджі, В. І. Федун, О. В. Цвєткова, А. В. Джеренова Приазовсъкий державний технічний університет, вул. Університетсъка, 7, Маріуполъ, 87555, Украӥна

У роботі досліджено вплив високоенергетичної імпульсно-плазмової обробки на модифікацію поверхні та трибологічні характеристики сірого чавуну на феритній основі з пластинчастим графітом (мікротвердість фериту становила $223 \pm 25 \mathrm{HV}$ ). Модифікацію проводили в атмосфері повітря з використанням електротермічного аксіального плазмового прискорювача за напруги дугового розряду $3.0 \mathrm{kB}$ та 4.0 кВ, що давало змогу отримати плазмовий потік із поверхневою щільністю потужності $1.0 \cdot 10^{9} \mathrm{~B}$ т $/ \mathrm{m}^{2}$ та $1.75 \cdot 10^{9} \mathrm{~B}$ т $/ \mathrm{m}^{2}$ відповідно. Як катод у прискорювачі використовували вольфрамовий стрижень. Дослідження виконано із застосуванням чисельного моделювання, оптичної мікроскопії (Eclipse M200 Nikon), електронної сканувальної мікроскопії (JSM-6510 JEOL), енергодисперсійної X-спектрометрії (JED-2300 JEOL), рентгенівської дифрактометрії (дифрактометр X'Pert PRO PANalytical з $\mathrm{CuK}_{\alpha}$-випромінюванням), вимірювання мікротвердості та випробувань на зношування за схемами "Three-body abrasion" (корундовий пісок) та "Ball-onDisk" (сухе тертя ковзанням). Результати досліджень показали, що після плазмового імпульсу зі щільністю енергії $1.0 \cdot 10^{9} \mathrm{~B}$ т $\mathrm{M}^{2}$ на поверхні чавуну сформувався модифікований шар глибиною до 12 мкм зі структурою дрібнозернистого мартенситу з мікротвердістю 359-652 HV (середнє значення - $535 \pm 88 \mathrm{HV}$ ); за цим режимом оплавлення поверхні не відбулося. Зі збільшенням щільності потужності до $1.75 \cdot 10^{9} \mathrm{~B} / \mathrm{m}^{2}$ температура поверхні сягнула $2300^{\circ} \mathrm{C}$, що викликало оплавлення на глибину 10-12 мкм, а загальна товщина модифікованого шару збільшилась до 28 мкм. Оплавлення спричинило розчинення графітних включень та збагачення розплаву вуглецем з наступним утворенням чарункової структури, яка складалась із дрібних (0.5-1.0 мкм) колоній ледебуритної евтектики "Аустеніт + карбід $\mathrm{Fe}_{3} \mathrm{C}$ " та високовуглецевого мартенситу 3 мікротвердістю 697-817 HV (середне значення - 747 $\pm 52 \mathrm{HV}$ ). Установлено, що плазмова обробка супроводжувалась поверхневою імплантацією модифікованого шару елементами, що входять до складу катоду, а саме: вольфрамом та міддю. Внаслідок ерозії катоду ці елементи переносились плазмовим потоком та легували розплав на поверхні чавуну, призводячи до утворення глобулярних карбідів вольфраму WC та легування фериту. Надшвидке $(\sim 2.0 \times 106 \mathrm{~K} / \mathrm{c})$ охолодження після плазмового нагріву призвело до утворення пересиченого твердого розчину міді з їі вмістом у фериті приблизно $3 \%$, що сприяло додатковому зміцненню модифікованого шару. Проведені дослідження на зношування показали, що плазмова модифікація викликала двократне збільшення зносостійкості сірого чавуну в умовах тертя по корундовому абразиву. Під час випробувань на сухе тертя ковзанням зафіксовано збільшення середнього значення коефіцієнта тертя, а також розкиду його поточних значень у модифікованому зразку порівняно з вихідним станом. Це пояснюється розчиненням графітних включень, що призвело до погіршення самозмащування поверхні в умовах сухого тертя ковзанням.

Ключові слова: імпульсно-плазмова обробка, модифікування, мікроструктура, мікротвердість, трибологічні властивості. 